Conference proceedings $2^{\text {nd }}$ and $3^{\text {rd }}$ Regional Innovation \& Entrepreneurship Conference

\title{
Corporate Social Responsibility in Regional and International Entrepreneurship
}

\section{Artyom Fakhrutdinov}

Russian Presidential Academy of National Economy and Public Administration, f37a@yandex.ru

Abstract: This paper is debating the regional implications of Corporate Social Responsibility in three important global economic regions. After an introduction of the concept of Corporate Social Responsibility, some characteristic of each region is presented. Also some good examples are given. In the conclusion it is emphasized that the application of Corporate Social Responsibility can advance both, the international position of Russian Businesses and the attractiveness for high talented experts.

Keywords: Corporate Social Responsibility, Russian Businesses, regional differences

\section{Introduction}

The topic of this article is Corporate Social Responsibility. The topic is chosen because it is essential struggle for modern business in Russia as well as in many countries abroad. Corporate Social Responsibility is a relatively new trend for Russian businesses, however most industry leaders have already started to run social programs. But if we want to develop and reach the level of international business we need changes to form socially responsible business. Still business has a long way to go to become really socially oriented and the economic situation in the world can now ruin all previous results.

This paper is divided into several main points: The definition of Corporate Social Responsibility, Arguments for businesses to be socially oriented and at the end of this paper, some successful examples of Corporate Social Responsibility are given. 
Conference proceedings $2^{\text {nd }}$ and $3^{\text {rd }}$ Regional Innovation \& Entrepreneurship Conference

\section{Definition of Corporate Social Responsibility}

In this section the definition of Corporate Social Responsibility is given. This is a form of corporate self-regulation integrated into a business model. Corporate Social Responsibility involves the usage of resources in the way they would bring benefits both to the owner and to society. From this definition in the next section arguments for businesses to be socially oriented will be addressed.

\section{Arguments for businesses to be socially oriented}

In this section, first the general arguments to apply Corporate Social Responsibility are given, followed by its mission. This section is closing with a list of benefits of the application of Corporate Social Responsibility. Since the very beginning business was closely operating with society. It could exist only in case there were people, for whom products and services were produced, for people who have demand for the product or service. These basic remained and things haven't changed even till nowadays. Business still depends on the society and it at the same time influences industry greatly. But we do need changes in terms of attitude from average entrepreneurs and businessmen.

Business has become more than just an economic unit. Now it is a part of complex surrounding consisting of various stakeholders like consumers, suppliers, massmedia, unions, employees and shareholders. It should definitely help the society, carrying out various social programs, cooperating with government. Social expectations concerning good corporate activities have already formed and your target audience is watching over every your move. So there is nothing left for corporations but to follow them in order to be successful.

\subsection{The regional differences of Corporate Social Responsibility}

Nowadays we can see the difference between how the look at Corporate Social Responsibility varies in different areas. Two major dominating models of Corporate Social Responsibility can be found: American and European. As the topic of this paper is "Corporate Social Responsibility in regional and international entrepreneurship" in the paragraph below, the Russian model is debated.

- American way of Corporate Social Responsibility is characterized as the one with most authorized enterprises. Corporate aims are - 
Conference proceedings $2^{\text {nd }}$ and $3^{\text {rd }}$ Regional Innovation \& Entrepreneurship Conference profitability and responsibilities in front of shareholders. Charity is also widely spread activity, highly appreciated by the society. A big percent of all social programs is financed through corporate funds and all the expenses on solving social problems reduce the amount of taxes paid by the corporation.

- European way is to pay higher taxes and thus give money to the government to carry out various social programs. Today European corporations are mostly focused on 3 main types of Corporate Social Responsibility: economy, employment and protection of the environment.

- Russian business hasn't decided yet which way to choose. In the beginning of 90-s American type of Corporate Social Responsibility was brought, but now our companies start to take interest in the European approach and consider social matters to be a very important part of their activity.

We can also define two main directions of realizing Corporate Social Responsibility missions: external - high quality goods, charity, sponsorship, environmental protection, education, transparency of accountancy, help for the regions etc. Internal model involves staff development, high salaries, medical insurance for employees, help in solving social problems for employee families (for example to find a place to live or a kindergarten for children). The most solid look at global problems belongs to the United Nations. They listed 17 Millennium development goals for sustainable communities development.

\subsection{The benefits of Corporate Social Responsibility}

Independent of the regional approach of Corporate Social Responsibility, an important number of benefits for businesses are identified. These benefits are listed below.

- $\quad$ Following moral standards and responsibilities

- Driver for changes for better performance

- $\quad$ Finding solutions for urgent social problems

- Changing customers' expectances and having closer relationship with the society

- Creation of excellent reputation

- Avoid contradictions with government and even getting support 
Conference proceedings $2^{\text {nd }}$ and $3^{\text {rd }}$ Regional Innovation \& Entrepreneurship Conference

Opportunities for partnership with like-minded people and projects

- Opportunities for expanding business and global integration

\section{Examples of Corporate Social Responsibility}

As is proposed in the above sections, it becomes a trend to become an Corporate Social Responsibility. Based on the characteristics of Corporate Social Responsibility it is possible to list companies and corporations, whose policy has become more socially oriented. There are only some of them: Google, IBM, Shell, Xerox, The Walt Disney Company, KPMG, BP, Barclays, Kraft Foods, Nike, Reebok, BMW, Peugeot and Daimler-Chrysler.

\section{Conclusions}

In the developed countries Corporate Social Responsibility is already an essential part of modern business. Many companies have admitted this way not only because of their own position in this matter, but because of social pressure. In opposite, the world is facing one of the greatest financial crises in history, many companies have already gone bankrupt and many others are on the way. The main tendencies of Corporate Social Responsibility development in Russia unfortunately are: stopping of various social programs, raising level of employee layoff, dishonest methods of gaining profits (some companies make employees work overtime or pay less under the threat of redundancy). The process of forming Corporate Social Responsibility will take a lot of time and effort, but the results worth this! 